\title{
Special Issue: UNCITRAL and Investment Arbitration Reform: Matching Concerns and Solutions
}

\section{An Introduction}

\author{
Malcolm Langford \\ PluriCourts, Faculty of Law, University of Oslo, Oslo, Norway \\ malcolm.langford@jus.uio.no
}

\author{
Michele Potestà \\ Geneva Center for International Dispute Settlement (CIDS), Graduate \\ Institute of International and Development Studies \& Geneva University \\ Law School, Geneva, Switzerland \\ michele.potesta@cids.ch \\ Gabrielle Kaufmann-Kohler \\ Geneva Center for International Dispute Settlement (CIDS), Graduate \\ Institute of International and Development Studies \& Geneva University \\ Law School, Geneva, Switzerland \\ gabrielle.kaufmann-kohler@cids.ch
}

\section{Daniel Behn}

Queen Mary University of London, London, United Kingdom d.behn@qmul.ac.uk

\begin{abstract}
The ongoing 'legitimacy crisis' in investor-State dispute settlement (ISDS) has triggered a comprehensive attempt at multilateral reform. In 2017, Working Group III at the United Nations Commission on International Trade Law (UNCITRAL) was entrusted with a broad, open-ended and problem-driven mandate. The reform process aims to tackle particular concerns with ISDS: excessive costs and lengthy proceedings, inconsistent and incorrect decisions, and a lack of arbitral diversity and independence.
\end{abstract}


The exclusion of substantive treaty reform has met critique but states are considering a wide range of procedural options from incremental reform to a multilateral court, appellate mechanism, and ISDS alternatives. In this article, we introduce the reform process and the seven articles that follow in this Special Issue of the Journal on World and Investment and Trade. In these contributions, ISDS Academic Forum members analyse the basis for each concern and the potential contribution of leading reform models.

\section{Keywords}

Academic Forum on ISDS - appellate review - investment arbitration reform investor-State dispute settlement (ISDS) - legitimacy crisis - multilateral investment court - United Nations Commission on International Trade Law (UNCITRAL) Working Group III

\section{The Rise of Reform}

Critique is no stranger to investor-State dispute settlement (ISDS). For at least a decade, the ISDS regime has suffered a public legitimacy crisis. ${ }^{1}$ Critics charge that the system is afflicted by pro-investor bias, undue secrecy, conflicting jurisprudence and high levels of compensation, which is compounded by concerns that developing countries are burdened with excessive legal costs and frequently lose cases against foreign investors. ${ }^{2}$ To be sure, the system has its defenders. They assert that concerns are exaggerated or overblown, and that the regime evolves to address criticism, attracts more support than is

1 Amongst the first scholarly critiques was Susan Franck, "The Legitimacy Crisis in Investment Treaty Arbitration: Privatizing Public International Law Through Inconsistent Decisions' (2005) 73 Fordham L Rev 107. The idea of a legitimacy crisis was well-established by 2010 with the publication of Michael Waibel and others (eds), The Backlash Against Investment Arbitration: Perceptions and Reality (Kluwer Law International 2010). For an analysis of the trajectory of the debate until now, see Malcolm Langford, Cosette Creamer and Daniel Behn, 'Regime Responsiveness in International Economic Disputes' in Szilárd Gáspár-Szilágyi, Daniel Behn and Malcolm Langford (eds), Adjudicating Trade and Investment Disputes: Convergence or Divergence? (CUP 2020) 244.

2 See eg Gus Van Harten, 'Arbitrator Behaviour in Asymmetrical Adjudication: An Empirical Study of Investment Treaty Arbitration' (2012) 50 Osgoode Hall L J 211, 251; Zachary Douglas, 'The MFN Clause in Investment Arbitration: Treaty Interpretation off the Rails' (2011) 2 JIDS 97; George Kahale 'Is Investor-State Arbitration Broken?' (2012) 7 TDM; 'The Arbitration Game: Governments Are Souring on Treaties to Protect Foreign Investors' The Economist (11 October 2014). 
acknowledged, protects genuinely vulnerable investors, and promotes investment and the rule of law. ${ }^{3}$ Nonetheless, ISDS continues to attract controversy. ${ }^{4}$ The number of cases has surged to well over one thousand, ${ }^{5}$ states' regulatory autonomy on sensitive subjects has been challenged in high profile cases, ${ }^{6}$ and the evidence of its contribution to public goods has been disputed. ${ }^{7}$

3 For example, the European Federation for Investment Law and Arbitration (EFILA) concludes that, " $\mathrm{t}]$ he bottom line of this analysis is that most of the criticisms are neither supported by the facts nor by the treaty practice and case law. The fact is that the system has been functioning satisfactorily and that it generally provides for adequate resolution of investment disputes.' European Federation for Investment Law and Arbitration (EFILA), A Response to the Criticism Against ISDS (17 May 2015) 42. See also Jason Fry, 'International Human Rights Law in Investment Arbitration: Evidence of International Law's Unity' (2007) 18 Duke J Comp \& Intl L 77 .

4 'The Arbitration Game' (n 2).

5 See the PITAD database at <www.pitad.org >; Daniel Behn and others, 'PITAD Investment Law and Arbitration Database: Version 1.0' (Pluricourts Centre of Excellence, University of Oslo, 31 January 2019).

6 See Kyla Tienhaara, 'Regulatory Chill and the Threat of Arbitration: A View from Political Science' in Chester Brown and Kate Miles (eds), Evolution in Investment Treaty Law and Arbitration (CUP 2011) 606; Gus Van Harten, Investment Treaty Arbitration and Public Law (OUP 2007); David Schneiderman, Constitutionalizing Economic Globalization (CUP 2008); and Kyla Tienhaara, 'Regulatory Chill in a Warming World: The Threat to Climate Change Posed by Investor-State Dispute Settlement' (2018) 7 TEL 229.

7 Early studies were mostly positive on the evidence or potential of the investment regime in enhancing foreign direct investment and domestic rule of law: see E Neumayer and L Spess, 'Do Bilateral Investment Treaties Increase Foreign Direct Investment to Developing Countries?' (2005) 33(10) World Development 1567; Peter Egger and Michael Pfaffermayer, 'The Impact of Bilateral Investment Treaties on Foreign Direct Investment' (2004) 32 Journal of Comparative Economics 787; Benedict Kingsbury and Stephan W Schill, 'Investor-State Arbitration as Governance: Fair and Equitable Treatment, Proportionality and the Emerging Global Administrative Law' (2009) IILJ Working Paper 2009/6 (Global Administrative Law Series), but see Mary Hallward-Driemeier, 'Bilateral Investment Treaties Attract Foreign Direct Investment? Only a Bit ... and They Could Bite' (2003) Policy Research Working Paper 3121. Later studies provide a negative or highly contingent picture on both investment and rule of law: see UNCTAD, The Role of International Investment Agreements in Attracting Foreign Direct Investment to Developing Countries 2 (2009); Alex Berger and others, 'Do Trade and Investment Agreements Lead to More FDI? Accounting for Key Provisions Inside the Black Box' (2014) 32(4) Journal of Comparative Economics 788; Shiro Armstrong and Luke Nottage, 'Mixing Methodologies in Empirically Investigating Investor-State Arbitration' in Daniel Behn, Ole Kristian Fauchald and Malcolm Langford (eds), The Legitimacy of Investment Arbitration: Empirical Perspectives (CUP 2020) (forthcoming); Jennifer Tobin and Susan Rose-Ackerman, 'When BITs Have Some Bite: The Political-Economic Environment for Bilateral Investment Treaties' (2010) 6 Review of International Organizations 1; Todd Allee and Clint Peinhardt, 'Contingent Credibility: The Impact of Investment Treaty Violations on Foreign Direct Investment' (2011) 65(3) Intl Org 401; Emma Aisbett, Matthias Busse and Peter Nunnenkamp, 'Bilateral Investment Treaties Do Work; Until They Don't' (2016) 
Unsurprisingly, these concerns have resulted in demands for reform from various states, international organizations, and civil society groups. In July 2017, the first major comprehensive attempt at ISDS reform was announced. ${ }^{8}$ At its 5 oth session, member states of the United Nations Commission on International Trade Law (UNCITRAL) entrusted Working Group III (WG III) with a broad, open-ended, and problem-driven mandate to address the real and perceived legitimacy of the current regime. ${ }^{9}$ The body would: identify concerns regarding ISDS; consider whether reform was desirable in the light of those concerns; and, if so, develop solutions. ${ }^{10}$ During their November 2018

Kiel Working Paper No 2021; Liesbeth Colen, Damiaan Persyn and Andrea Guariso, 'Bilateral Investment Treaties and FDI: Does the Sector Matter?' (2016) 83 World Development 193; Thomas Schultz and Cédric Dupont, 'Investment Arbitration: Promoting the Rule of Law or Over-Empowering Investors? A Quantitative Empirical Study' (2015) 25(4) EJIL 116o; Jason Yackee, 'Bilateral Investment Treaties, Credible Commitment, and the Rule of (International) Law: Do BITs Promote Foreign Direct Investment?' (2008) 42(4) Law and Society Review 805; and Susan Franck, 'Foreign Direct Investment, Investment Treaty Arbitration, and the Rule of Law' (2007) 19(2) Pacific McGeorge Global Business and Development Law Journal 337.

8 The process emerged gradually in 2015, when the UNCITRAL Secretariat commissioned a study to the Geneva Center for International Dispute Settlement (CIDS) to review whether the Mauritius Convention on Transparency could provide a useful model for possible reforms in the field of investor-State arbitration. See United Nations, 'Report of the United Nations Commission on International Trade Law, Forty-Eighth Session' (29 June-16 July 2015), Official Records of the General Assembly, Seventieth Session, Supplement No 17, UN Doc A/70/17, para 268. The Report was published in June 2016. See Gabrielle Kaufmann-Kohler and Michele Potestà, 'Can the Mauritius Convention Serve as a Model for the Reform of Investor-State Arbitration in Connection with the Introduction of a Permanent Investment Tribunal or an Appeal Mechanism? Analysis and Roadmap' (CIDS 2016) <www.uncitral.org/pdf/english/CIDS_Research_Paper_Mauritius.pdf> accessed 14 February 2020. The CIDS Report was presented at the 49th session of the UNCITRAL Commission in 2016. See United Nations, 'Report of the United Nations Commission on International Trade Law, Forty-Ninth Session' (27 June-15 July 2016) Official Records of the General Assembly, Seventy-First Session Supplement No 17, UN Doc A/71/17, paras 187-194. In 2017, the UNCITRAL Secretariat commissioned a further study from the CIDS: see Gabrielle Kaufmann-Kohler and Michele Potestà, 'The Composition of a Multilateral Investment Court and of an Appeal Mechanism for Investment Awards' (CIDS 2017) <www.uncitral.org/pdf/english/workinggroups/wg_3/CIDS_Supplemental_ Report.pdf $>$ accessed 14 February 2020.

9 United Nations Commission on International Trade Law (UNCITRAL), 'Report of Working Group III (Investor-State Dispute Settlement Reform) on the Work of Its Thirty-Fourth Session (Vienna, 27 November-1 December 2017)' UN Doc A/CN.9/930/ Rev.1 (19 December 2017).

10 See United Nations, 'Report of the United Nations Commission on International Trade Law, Fiftieth Session' (3 July-21 July 2015), Official Records of the General Assembly, Seventy Second Session, Supplement No 17, UN Doc A/72/17, paras 263-64. 
meeting in Vienna, WG III identified six concerns to be addressed by the reform process: (1) excessive legal costs; (2) duration of proceedings; (3) legal consistency; (4) decisional correctness; (5) arbitral diversity; and (6) arbitral independence and impartiality. ${ }^{11}$ Moreover, several other issues have emerged in the process, such as third-party funding, prevention of investment disputes and calculation of damages. ${ }^{12}$

To be sure, this initiative is not the first reform endeavour. Since 2004, certain states, arbitral centers and international organisations have attempted to initiate change. ${ }^{13}$ This has included withdrawal from the Convention for the Settlement of Investment Disputes between States and Nationals of Other States (ICSID Convention) $)^{14}$ and certain investment treaties, development of new model treaties, replacement of arbitration with a court-like system, ${ }^{15}$ substantive reform of existing treaties, ${ }^{16}$ and revision of procedural rules. ${ }^{17}$ However, many considered the result a patchwork. Reforms lacked depth (only

11 UNCITRAL, 'Possible Reform of Investor-State Dispute Settlement (ISDS)' UN Doc A/CN.9/WG.III/ WP.149 (5 September 2018).

12 Malcolm Langford, 'UNCITRAL and Investment Arbitration Reform: A Little More Action' (Kluwer Arbitration Blog, 21 October 2019) <http://arbitrationblog.kluwer arbitration.com/2019/10/21/uncitral-and-investment-arbitration-reform-a-little-more -action/?doing_wp_cron=15906990oo.8345720767974853515625> accessed 16 March 202O.

13 Taylor St John, The Rise of Investor-State Arbitration: Politics, Law, and Unintended Consequences (OUP 2018) ch 8; Malcolm Langford, Daniel Behn and Ole Kristian Fauchald, 'Backlash and State Strategies in International Investment Law' in Tanja Aalberts and Thomas Gammeltoft-Hansen (eds), The Changing Practices of International Law (CUP 2018) 70-102.

14 Convention on the Settlement of Investment Disputes Between States and Nationals of Other States (International Centre for Settlement of Investment Disputes [ICSID] 575 UNTS 159 (entered in force 14 October 1966), arts 14 and 40.

15 See eg Comprehensive Economic and Trade Agreement Between Canada, of the One Part, and the European Union and Its Member States, of the Other Part, Official Journal of the European Union L11/23 (signed 30 October 2016, entered into force 21 September 2017) (CETA).

16 See eg Agreement Between the United States of America, the United Mexican States, and Canada (USMCA) ('NAFTA 2.0') (signed 29 January 2020). States have recently initiated a new process to modify the Energy Charter Treaty, 2080 UNTS 100 (signed 17 December 1994, entered into force 16 April 1998) according to the mandate of its state contracting parties.

17 In this respect, it is important to note that UNCITRAL is not the only multilateral or plurilateral effort to reform the manner in which disputes are resolved under investment treaties. ICSID for example has initiated several processes over the past decade to reform rules applying in ICSID disputes; arbitral institutions (principally the ICC and SCC) have modified or added rules to allow for better administration of ISDS disputes. 
selected issues were tackled) and breadth (only a few states were involved and many solutions require bilateral or plurilateral consensus).

Moreover, there were particular reasons why UNCITRAL emerged as a space for discussions on comprehensive reform. UNCITRAL WG III was available for a new mandate; the secretariat had completed a series of scoping studies; and the open membership of UNCITRAL offered the European Union (EU) a multilateral arena in which to pursue its structural reforms. And, with the adoption of a transparency convention, the organisation could boast of its role in creating a model for multilateral ISDS reform..$^{18}$

However, the UNCITRAL reform process is subject to an important caveat. The mandate is implicitly limited to procedural reforms, such that reform of the substantive rules in investment treaties is largely excluded..$^{19}$ This carveout and its interpretation has attracted critique. ${ }^{20}$ It is partly normative. Many claim that the core concerns with the system identified by WG III cannot be addressed without accompanying substantive reform to the underlying rules. ${ }^{21}$ It is also legal. Some states and scholars argue that there is no consensus that substantive treaty reform is excluded under the mandate. ${ }^{22}$ Moreover, it is contended that the distinction between procedural and substantive is often

18 Mauritius Convention on Transparency in Treaty-Based Investor-State Arbitration 2014 (adopted 10 December 2014, entered into force 18 October 2017) (Mauritius Convention on Transparency). See also Kaufmann-Kohler and Potestà, 'Can the Mauritius Convention' (n 8).

19 This is extrapolated from the mandate which refers to 'regarding ISDS'.

20 Georgios Dimitropoulos, "The Conditions for Reform: A Typology of "Backlash" and Lessons for Reform in International Investment Law and Arbitration' (2020) 19 LPICT 416.

21 See Anthea Roberts and Taylor St John, 'UNCITRAL and ISDS Reforms: Agenda-Widening and Paradigm-Shifting' (EJL: Talk!, 2o September 2019) <www.ejiltalk.org/uncitral-and -isds-reforms-agenda-widening-and-paradigm-shifting/> accessed 16 March 2020. See also Submission from South Africa to the United Nations, UN Doc A/CN.9/WG.III/WP.176 (17 July 2019) para 20: the 'Working Group would not be fully discharging its mandate if discussions on the substantive reforms were excluded'.

22 For example, see the exchange of states in United Nations, 'Report of the United Nations Commission on International Trade Law, Fiftieth Session' (3-21 July 2017) para 257: 'It was mentioned that work on investor-State dispute settlement reform should not be limited to procedural issues relating to investor-State dispute settlement but should encompass a broader discussion on the substantive aspects of international investment agreements, including but not limited to States' right to regulate, fair and equitable treatment, expropriation and due process requirements.' See discussion of legal interpretation of the mandate in Gus Van Harten, Jane Kelsey and David Schneiderman, 'Phase 2 of the UNCITRAL ISDS Review: Why "Other Matters" Really Matter' (2019) Osgoode Legal Studies Research Paper 2. 
illusory. ${ }^{23}$ Substantive provisions shape the asymmetric contours of the process (e.g. only investors not affected communities have rights), while ISDS has a transformative effect on substantive provisions (e.g. expanding or shrinking investor protections).

In practice, this mandate dispute has been resolved pragmatically and with reliance on the strategic ambiguity in wording. On one hand, the strict procedural interpretation has been defended on the basis of feasibility: limited time and the challenge of reforming thousands of treaties simultaneously. ${ }^{24}$ Moreover, only a fragile consensus existed initially for wide-ranging procedural reforms - with considerable opposition to the process from some major powers such as the United States and Russia. Finding a broader consensus to address substantive aspects would have been challenging, especially since there is no agreement amongst states on whether there are substantive problems with the underlying treaties. On the other hand, it has been acknowledged by the Working Group chair and others that the mandate is flexible and some space can or may be given to discussion of substantive reforms. ${ }^{25}$ It is also clear that some proposed procedural reforms will perforce have substantive implications ${ }^{26}$ and that the envisaged legal architecture for reform could create space for states to more easily discuss and enact changes to the substantive provisions of investment treaties.

This Special Issue is devoted largely to assessing the contribution of different procedural reform options to the identified concerns. Through research by the Academic Forum on ISDS, a scholarly network tracking and participating in the process, ${ }^{27}$ the articles focus on the utility of the range of procedural reforms. These range from the 'lighter' to the 'heavier' options: maintaining

23 Alessandri Arcuri and Federica Violi, 'Human Rights and Investor-State Dispute Settlement: Changing (Almost) Everything, So that Everything Stays the Same?' (2019) 3 Diritti umani e diritto internazionale 579 .

24 There are over 2600 international investment agreements in force. Mostly bilateral agreements, but some plurilateral ones. About 90\% of the investment treaties available and coded on UNCTAD up to 2017 include ISDS; see UNCTAD Investment Policy Hub $<$ https://investmentpolicy.unctad.org> accessed 16 March 2020. Approximately 9o\% of agreements contain ISDS clauses. See also Joachim Pohl, Kekeletso Mashigo and Alexis Nohen, 'Dispute Settlement Provisions in International Investment Agreements: A Large Sample Survey' (2012) OECD Working Papers on International Investment 2012/o2 (96\% of the 1,66o bilateral investment treaties surveyed contain ISDS language).

25 See discussion in Malcolm Langford and Anthea Roberts, 'UNCITRAL and ISDS Reform: Hastening Slowly' (EJIL:Talk!, 29 April 2019) <www.ejiltalk.org/uncitral-and-isds -reforms-hastening-slowly/> accessed 16 March 2020.

26 See eg Lise Johnson and others, 'Clearing the Path: Withdrawal of Consent and Termination as Next Steps for Reforming International Investment Law' (April 2018) CCSI Policy Paper.

27 See description in Section 3 below. 
the existing investor-State arbitration system with targeted adjustments, to establishing an appeal mechanism, a permanent court and the elimination of ISDS. However, this focus on the procedural aspects is not to imply that the complex interplay between procedure and substance or the possibility for substantive reform is ignored by either the ISDS Academic Forum working groups or scholars more generally. ${ }^{28}$

In the remainder of this introductory article, we set out the framework for the analysis, introduce the Academic Forum on ISDS, and summarise the findings from the seven articles that form part of this Special Issue.

The initial challenge for WG III in the second phase consisted in assessing whether the identified six key concerns about ISDS were well-founded and serious enough to justify systemic reforms. In April 2019, WG III met in New York and agreed that reform was necessary. ${ }^{29}$ However, it is clear from plenary discussions in the third phase that dissensus persists amongst states as to how seriously they treat different critiques of the system. It inflects how they frame, weigh and shape possible reform options. Thus, the systematic assessment of the identified concerns from empirical and legal perspectives in the articles in this Special Issue is of ongoing relevance.

The subsequent challenge, which is central in the current third phase of the negotiations, is how to evaluate competing solutions. ${ }^{30}$ To be sure, there are different ways of framing the envisaged and emerging reform options. ${ }^{31}$ Four can be named.

28 See eg Anthea Roberts and Taylor St John, 'UNCITRAL and ISDS Reform: Visualising a Flexible Framework' (EJLL: Talk!, 24 October 2019) <www.ejiltalk.org/uncitral-and-isdsreform-visualising-a-flexible-framework/> accessed 16 March 2020; Diane Desierto and others, 'Damages and Reform' (2020) Academic Forum on ISDS Concept Paper 2020/18 (forthcoming); Van Harten, Kelsey and Schneiderman (n 22).

29 UNCITRAL, 'Report of Working Group III (Investor-State Dispute Settlement Reform) on the Work of Its Thirty-Seventh Session (New York, 1-5 April 2019, published 9 April 2019)' UN Doc A/CN.9/970.

30 For an overview of the discussion on the first three proposed solutions (advisory centre for developing states, code of conduct for arbitrators, and third-party funding), see Julian Arato, 'ISDS Reform: Working Group III Gets Down to Brass Tacks' (International Litigation Blog, 22 October 2019) <http://international-litigation-blog.com/isds-reform -working-group-iii-gets-down-to-brass-tacks/> accessed 16 March 2020.

31 Anthea Roberts and Taylor St John, 'UNCITRAL and ISDS Reforms: Battles over Naming and Framing' (EJIL: Talk!, 30 April 2019) <www.ejiltalk.org/uncitral-and-isds-reforms -battles-over-naming-and-framing/> accessed 16 March 2020. 
First, and politically, states have been placed by Anthea Roberts into three categories: ${ }^{32}$ 'incrementalists' favour retaining the existing form of ISDS with modest reforms to redress specific concerns; 'systemic' reformers wish to retain the right of foreign investors to seek international relief but champion new ways of structuring dispute resolution, such as through a court or appellate review; while paradigm shifters argue for wholesale replacement of ISDS and embrace alternatives such as domestic courts, ombudsmen, and state-tostate arbitration.

Second, and conceptually, the Working Group divides its proposals in the third phase by whether they require structural or non-structural reform. Structural reform refers to the need to create new international institutions such as a court, appellate mechanism or advisory centre; ${ }^{33}$ while non-structural reforms refer to only the use of textual modalities in soft and hard law instruments. Since April 2019, this typology has set the basis for time allocation in WG III with equal time to be devoted to each type of reform in the agenda.

Third, and pragmatically, the agenda was organized for 2019/2020 according to a workable, but somewhat untidy combination of distinct concerns or reform proposals. States agreed to discuss multiple solutions simultaneously, as opposed to sequentially. ${ }^{34}$ For example, over three sessions states have discussed in the following order: an advisory centre for developing states, code of conduct for arbitrators, third-party funding, appellate mechanism, multilateral investment court, selection and appointment of adjudicators, reflective loss claims, prevention and mediation of disputes, treaty interpretation, concurrent proceedings (including counter-claims) and overall reform architecture. When the physical negotiations commence again after the COVID-19 lockdowns, we are likely to see a similar type of bricolage timetable although based on some overall underlying reform design. ${ }^{35}$

32 Anthea Roberts, 'Incremental Systemic, and Paradigmatic Reform of Investor-State Arbitration' (2018) 112(3) AJIL 410.

33 Structural proposals so far include an appellate mechanism, a multilateral investment court, a court plus an appellate mechanism and an advisory centre for developing states, with a discussion as to whether this should be open to small and medium investors, while non-structural options include 'other potential solutions' such as a code of conduct for arbitrators, restricting reflective loss claims for shareholders, regulating third-party funding and expanding the possibility for counter-claims; together with a range of hybrid proposals to increase state control of treaty interpretation, new mechanisms for selection of arbitrators and alternative dispute resolution. UNCITRAL (n 29) para 82.

35 UNCITRAL, 'Possible Reform of Investor-State Dispute Settlement (ISDS)' (30 July 2019) UN Doc A/CN.9/WG.III/WP.166. 
Finally, and analytically, the reform options can be placed in four general categories, which forms the framework for this Special Issue. These options are:

- improvement of the existing investor-State arbitration system (IA improved); $; 6$

- addition of an appellate mechanism to the current investment arbitration regime (IA + appeal);

- introduction of a multilateral investment court (with or without an builtin appeal) (MIC);

- rejection of ISDS, with two sub-scenarios, namely (i) recourse to domestic courts only, and (ii) recourse to State-to-State arbitration, with or without prior mandatory recourse to domestic courts (No ISDS).

When we embarked on this project in 2018, it appeared then (and it continues to appear at the time of writing) that these four scenarios (and sub-scenarios) are the main ones advanced in the discussions around ISDS reform and reflect the principal alternatives available for the design of dispute settlement systems. They represent the broad spectrum of positions and views expressed in recent State practice and in the debate surrounding investment arbitration. Moreover, these scenarios combine the above political and conceptual distinctions: The first approach is largely incremental, the next two systematic and structural, and the final paradigmatic.

This being said, the choice of the four reform scenarios calls for three comments. First, while these four models can be condensed into a few base features, the details and options that must be considered in order to construct each of them are both numerous and complex. ${ }^{37}$ Modest improvements of the existing investor-State arbitration regime might range from creating a single rule on arbitral appointment (e.g. a restriction or ban on arbitrators double hatting as counsel) to a panoply of reforms regulating third-party financing, arbitrator disclosures, and calculation of legal costs. Likewise, in creating an appellate mechanism there are important and consequential choices to make over appointment (from a roster to permanent), substantive jurisdiction (narrow or broad), and powers (e.g. possibility of de novo review). Assessing the implications of each reform is thus challenging. Moreover, states and scholars have only begun to identify how a single reform package might encompass all

$3^{6}$ This option could include in particular changes in respect of the appointment of and rules of conduct for arbitrators, eg providing for appointment predominantly by arbitral institutions or effected jointly by disputing parties; roster-system; adoption of ethical rules, or other procedural changes.

37 See discussion of model building in Malcolm Langford, Daniel Behn and Mariachiara Malaguti, 'The Quadrilemma: Appointing Adjudicators in Future Investor-State Dispute Settlement' (13 October 2019) Academic Forum on ISDS Concept Paper 2019/12. 
of the proposed reforms. For example, a so-called Multilateral Convention on Procedural Reform would permit states to opt-in for their preferred options and accept bilateral obligations concerning investment disputes when their choices are matched by other states. ${ }^{38}$

Second, while each of these reform options may exist in a 'pure' form, some of them could well be combined. For instance, states could design dispute settlement mechanisms in which access to ISDS or the MIC is conditioned upon recourse to domestic courts. However, in order not to overly complicate the exercise, the papers have mainly addressed the relevant concern under the four reform constellations without systematically considering combinations.

Third, the choice of the four reform scenarios is limited to dispute settlement mechanisms leading to a binding decision. This means that the articles in this Special Issue do not examine methods such as mediation, conciliation, ombudsman, etc. This limitation in no way implies any judgment on the usefulness of these alternative mechanisms, and some of them are the subject of a current Academic Forum study. ${ }^{39}$ It was adopted because these methods are often combined with one of the binding options envisaged by the articles in the Special Issue and time constraints in completing a project of this magnitude in a timeframe aligned with the progress of WG III.

\section{Scholarly Assessment}

Turning to the authors of the articles, it is important to highlight the role of research in WG III. Unlike most UNCITRAL reform processes, states were clear from the outset that the process was to be 'government-led. ${ }^{40}$ Experts were to play observer and advisory rather than representational roles. However, noting that the criticism about investor-State arbitration is often polarized, the mandate for WG III highlights that its work 'should not be undertaken based on mere perceptions, but on facts. ${ }^{41}$ This has opened the space for stakeholders, whether from academia, civil society, practitioners and investor organisations, to play an important role in providing evidence. Although advocacy based on

38 See Roberts and St John (n 28); Stephan W Schill and Geraldo Vidigal, 'Designing Investment Dispute Settlement à la carte: Insights from Comparative Institutional Design Analysis' (2019) 18 LPICT 314.

39 Catherine Kessedjian and others, 'Mediation [in Future] Investor-State Dispute Settlement' (5 March 2020) Academic Forum on ISDS Concept Paper 2019/16.

$40 \quad \mathrm{UN}(\mathrm{n} 10)$ para 251.

41 UNCITRAL, 'Report on the Fiftieth Session' (n 22) para 245. 
normative positions by different groups and individual scholars as observers is also a distinct part of the process.

In 2018, in that spirit and context, the Geneva Center for International Dispute Settlement (CIDS) facilitated the creation of the 'Academic Forum on ISDS' ${ }^{42}$ The purpose was to facilitate the engagement of academics in the process in order to exchange views, explore issues and options, test ideas and solutions, and hopefully make a constructive and research-based contribution. Given the large spectrum of views on what problems require reform and what reforms best address those problems, there is a clear need for objective, neutral, and data-driven research and working methods that can provide input into the process. PluriCourts at the University of Oslo is the current administrator of the Academic Forum, ${ }^{43}$ which is led by a chair, three deputy chairs and a steering committee. ${ }^{44}$

The membership of almost one hundred scholars is quite diverse and all members are required to publicly disclose all engagements in arbitral practice. In addition to generating research, the group has also prepared language glossaries for states on ISDS, hosted side events at UNCITRAL, provided ongoing analysis of the process, and facilitated members' participation as observers in the various sessions. ${ }^{45}$ In addition, the ISDS Academic Forum received a specific request in April 2019 to provide research to states on the topic of selection and appointment of adjudicators; and after the onset of the COVID-19 crisis in 2020, has co-hosted with the UNCITRAL secretariat a series of webinars on different WG III themes. ${ }^{46}$

The present Special Issue grew out of the Academic Forum's first collective research exercise. ${ }^{47}$ The six core articles explore which reform options could meet the various criticisms voiced against the current ISDS regime.

42 It was founded by two of the authors of this introduction, Gabrielle Kaufman-Kohler and Michele Potestà.

43 Academic Forum on ISDS < http://bit.ly/isds-academic-forum > accessed 16 March 2020.

44 Malcolm Langford is the chair along with Daniel Behn as deputy chair. The others are: Mohamed Abdel Wahab (Deputy Chair), Andrea Bjorklund (Deputy Chair) and George Bermann, Stavros Brekoulakis, Diego P Fernández Arroyo, Gabrielle Kaufmann-Kohler, Won Kidane, Chi Manjiao, Michele Potestà, Anthea Roberts and Catharine Titi.

45 Academic Forum on ISDS (n 43).

46 UNICTRAL (n 29) para 84. For the webinar series, see $<$ https://uncitral.un.org/en/working_groups/3/investor-state $>$ accessed 12 June 2020 .

47 The idea emerged at the inaugural meeting of the Academic Forum on ISDS, held on 26 April 2018, with the aim of providing State delegations with academic support for their deliberation on the reform of ISDS. The project was designed by Gabrielle Kaufmann-Kohler, George Bermann, and Michele Potestà. 
Working groups of five to nine members were formed. ${ }^{48}$ Furthermore, given the emphasis on basing reform discussions on verifiable data, the project has put particular emphasis on the collection and analysis of empirical data relating to ISDS. Thus, a specific working group on empirical perspectives was also created. It has supported the other working groups with empirical evidence and its extensive review of the empirical evidence constitutes the first article in this Special Issue.

The draft papers produced by the working groups were circulated for comments to all members of the Forum, and were subsequently presented at the Academic Forum's first annual conference, held on 1-2 February 2019 at the University of Oslo ${ }^{49}$ and an UNCITRAL WG III side event on 2 April 2019 in New York with accompanying blogs in EJIL: Talk!. ${ }^{50}$ Since then, the papers have been subjected to additional peer review and thoroughly revised. While the articles benefitted from broad consultations, each article remains under the sole responsibility of each author and authorship cannot be attributed to the Academic Forum on ISDS.

\section{Overview of Articles and Main Findings}

With the exception of the empirical article, each article examines whether and, if so, how and to what extent an identified concern (costs, duration of proceedings, correctness, consistency, diversity, and independence and impartiality) would be addressed under four reform options listed above: IA improved, IA + appeal, MIC and No ISDS. Each article draws its own conclusions regarding the suitability of the reform options to address the relevant concern.

In the opening article, Behn, Langford and Létourneau-Tremblay seek to provide a state-of-the-art summary and assessment of the empirical research on the identified concerns of states in the reform of investment treaty arbitration

48 All Academic Forum members were invited to express their interest in participating in one or more of the seven working groups. The working groups were then composed on the basis of the preferences expressed by individual members and with an eye on a diverse and balanced composition of the groups. Each working group was coordinated by one chair or two co-chairs. The composition of the seven working groups is set out in each of the concept papers.

49 Particular papers were also discussed at a Forum meeting at the University of Vienna in October 2018.

$50 \quad$ Available at $<$ http://bit.ly/isds-academic-forum-blogs-april-2020 > accessed 14 February 2020. 
in UNCITRAL WG III. ${ }^{51}$ They ask two simple but difficult questions concerning the debate investment arbitration: (1) What do we know? and (2) Does it matter? Their survey of the empirical evidence reveals an emerging base of quantitative and qualitative evidence for assessing both the nature of concerns and their causes but also the limitations of an empirical perspective. There are challenges in accessing all relevant data (e.g. all final awards), modelling outcomes (e.g. capturing all determinants of arbitral behavior), and covering all questions (the empirical research community is small). Moreover, evaluative challenges remain. It was not always clear whether there was normatively a problem even when the research was clear. Nonetheless, the authors found that there is clear evidence of a problem with diversity and legal costs, but questions remain over whether duration is a major concern. In the remaining three areas, less is empirically known and the available evidence is not conclusive. It is challenging to empirically estimate the degree of inconsistency and incorrectness and empirical research on independence is in its infancy although there is some evidence of affiliation bias and potential conflicts of interests.

The other six articles each address a specific concern with the existing ISDS system and look at potential solutions to address it. The first concerns the challenge of excessive costs and recoverability of cost awards. Bottini and others analyse legal fees, the impact of the length of proceedings on costs, and the issue of insufficient resources to bring or defend against an investment claim. ${ }^{52}$ In so doing, they assess also the positive and negative role of third-party funding (TPF) and contingency and conditional fee arrangements; and examine the insufficient recoverability of cost awards. They focus particularly on the unavailability of mechanisms to secure prompt payment of a cost award where there are insufficient resources or an unwillingness to pay. The article finds that each reform option can positively affect the excessiveness of costs and recoverability but that it is partly depends on the design; and, in some cases, certain reform options might have a negative consequence.

Linked closely to concerns over costs, is the duration of proceedings. With a data-centric approach, Álvarez Zárate and others review claims concerning the excessive length of proceedings. ${ }^{53}$ After problematizing and analyz-

51 Daniel Behn, Malcolm Langford and Laura Létourneau-Tremblay, 'Empirical Perspectives on Investment Arbitration: What Do We Know? Does It Matter?' (2020) 21(2-3) JWIT 180-25o.

52 Gabriel Bottini and others, 'Excessive Costs and Recoverability of Cost Awards in Investment Arbitration' (2020) 21(2-3) JWIT 251-99.

53 José Manuel Álvarez Zárate and others, 'Duration of ISDS Proceedings' (2020) 21(2-3) JWIT $300-35$. 
ing the notion of 'excessive' length of proceedings, the article presents data on the duration of investment arbitration proceedings from different data sets - providing a mixed picture of whether there is a significant concern. As a possible comparator, the article looks at the length of proceedings before the Dispute Settlement Body of the World Trade Organization. After examining the various reform proposals and their likely impact on the length of ISDS proceedings, the authors observe that, despite the perception that the duration of investment arbitration proceedings is excessive, few, if any, of the reform proposals are designed specifically to tackle this concern. None of the proposed solutions, in and of themselves, are certain to achieve the goal of remedying excessive duration of proceedings. Instead, whether concerns about duration will be resolved depends on the construction of each mechanism and the article provides some pointers in that regard. However, the authors warn that efforts to speed up proceedings may sometimes come at the cost of due process, which should be taken into consideration in the overall reform design.

Turning to the substance of arbitration, Arato, Brown, and Ortino examine consistency in the interpretation of investment treaty provisions, with an eye to reform. ${ }^{54}$ The authors argue that inconsistency in the interpretation of 'standards' may be less problematic than inconsistent interpretations of 'rules'. Their article examines specifically the jurisprudence on select treaty provisions where inconsistent interpretations have arisen, including full protection and security, fair and equitable treatment, the relationship between investment treaties and contracts, and the scope of most-favoured-nation clauses. The authors conclude by noting that two types of solutions are available. At the 'front end', states can clarify particular norms in their investment treaties and, at the 'back end', systemic reforms to ISDS could mitigate the problem of inconsistency. In this respect, the authors state that procedural reforms that lead to the pronouncements of a single authoritative judicial voice would likely lead to greater consistency in interpretation across the board, although there are benefits and drawbacks to such structural reforms. The authors suggest that, at a minimum, states should keep sight of viable targeted front-end solutions while they consider the various long-term structural options for ISDS reform on the agenda at UNCITRAL (and beyond).

54 Julian Arato, Chester Brown and Federico Ortino, 'Parsing and Managing Inconsistency in ISDS' (2020) 21(2-3) JWIT 336-73. This article develops the earlier working group paper authored by Julian Arato, Yas Banifatemi, Chester Brown, Diane Desierto, Fabien Gelinas, Csongor Istvan Nagy, Federico Ortino. The paper is: 'Lack of Consistency and Coherence in the Interpretation of Legal Issues' (preliminary draft, 30 January 2019) Academic Forum on ISDS Concept Paper 2019/3. 
A key critique of ISDS has been the incorrectness of decisions, but it is arguably the most difficult concern to measure and evaluate. De Luca and others evaluate the correctness of decisions with a range of methods and potential policy responses to 'incorrect' ISDS decision-making. ${ }^{55}$ Their article begins by analysing distinct categories of criticism of 'incorrect' decision-making, in particular (i) criticism under existing review mechanisms, specifically by International Centre for Settlement of Investment Disputes (ICSID) ad hoc committees and, in non-ICSID cases, by courts at the arbitral seat under various domestic arbitration laws; (ii) criticism through State practice, including joint interpretations, non-disputing Party submissions, treaty drafting, and treaty negotiating history; and (iii) other sources of criticism, including criticism by arbitrators, scholars, and international organizations and as evidenced in empirical research. The article then examines the extent to which each of the categories of incorrect ISDS decision-making identified can be addressed under each of the four reform scenarios and which actors could support the correct identification of applicable law, including the correct identification of customary international law. Through incremental approaches, various actors and instruments could ensure that are less likely to be excessively broad or narrow in scope, not supported by treaty text, or unworkable in practice, but eliminating the risk of such interpretations would remain challenging - and even more so without ISDS. According to the authors, institutionalization, including appellate mechanisms or a multilateral investment court, would lead likely to advances in finality, predictability, and coherence in ISDS decisionmaking, but the extent to which these options would lead to advances in correctness - i.e. the correct identification and precise application of applicable law - is less clear.

Moving to the arbitrators themselves, UNCITRAL WG III has evinced considerable concern with diversity. Bjorklund and others, illustrate why adjudicator diversity constitutes an area of concern for the legitimacy of the ISDS system. ${ }^{56}$ Studies show that nearly all of the most prominent and repeatedly appointed arbitrators in ISDS cases are men from the Global North with significant prior experience in ISDS cases. Looking at these attributes of gender, geography and experiences, the authors address claims by critics that this lack of diversity has implications for both the quality and rigor of the decisions rendered but also for the way in which decisions are perceived as fair, just and absent of bias. To be sure, while diversity can include a wide variety of differing

55 Anna De Luca and others, 'Responding to Incorrect ISDS Decision-Making: Policy Options' (2020) 21(2-3) JWIT 374-409.

$5^{6}$ Andrea K Bjorklund and others, 'The Diversity Deficit' 21(2-3) JWIT (2020) 410-40. 
attributes, the authors focus mostly, but not exclusively, on proposals for more new entrants (less stale) who are women (not male) and more geographically diverse (less pale). The article is built around five different themes that are context specific. They assess how a lack of decision-maker diversity can affect the real and perceived legitimacy of the ISDS system; provide empirical evidence on the extent of the diversity problem in ISDS; explain the causes for the persistent diversity deficit in ISDS; examine what can be done to improve diversity in ISDS; and evaluate how the various reform options will impact the diversity question under any reformed ISDS system. The authors conclude that a variety of structural barriers perpetuate the lack of diversity under the current ISDS system and that most reform options are not particularly well situated to provide a diverse, inclusive, and representative set of adjudicators either. At a minimum, is it clear that there are no quick fixes and that resolving the diversity problem in ISDS will require both a long-term persistent effort involving major structural reforms. They stress the need for states to be committed to diversity in whatever type of dispute settlement system they opt for.

The final article delves into the requirement that adjudicators in investment dispute settlement are and remain independent and impartial. ${ }^{57}$ Giorgetti and others begin by providing a framework and understanding of the principle of independence and impartiality in arbitral institutions and international courts and tribunals. They highlight eight distinct concerns with the present system of investor-State arbitration, from party appointment to multiple appointments and inappropriate contact between arbitrators and parties. The authors provide a comparative analysis of how the different reform proposals presently discussed within UNCITRAL WG III would fare in terms of delivering a dispute resolution mechanism that ensures independence and impartiality. Rather than providing one specific solution, this article develops and uses a framework to assess different options for both policy-makers considering reform and other stakeholders and scholars. They find that there is much lowhanging fruit amongst the 'ISDS improved' options, such as the creation of a Code of Conduct for Arbitrators, but a more systemic approach reforms may provide greater independence and impartiality, although it is partly a function of the design of structural reform.

57 Chiara Giorgetti and others, 'Lack of Independence and Impartiality of Arbitrators' 21(2-3) JWIT (2020) 441-74. 
The core of the UNCITRAL WG III reform process is how to address the peculiarities that have emerged from the combination of substantive investor rights under international law with a particular form of international dispute settlement - arbitration. While slightly different in form - depending on the arbitral institution hosting the arbitration, the arbitrators selected, and underlying treaty-ISDS arbitration possesses the same fundamental structure. With some exceptions, arbitration flows one-way with a single category of litigant (a foreign investor on the claimant side and a state hosting the investment on the respondent side); are one-off as they are constituted to solve a particular dispute; is adjudicated upon by arbitrators, not judges, that are most often appointed by the parties to the dispute; is framed by rules on transparency that while increasingly far from completely opaque are not comparable to a fully public system of adjudication. ${ }^{58}$

While investor-State arbitration was applauded in its early days - as a solution to many problems experienced in resolving foreign investment disputes with sovereigns (especially those related to access to domestic courts), it has struggled to maintain its legitimacy and partly its effectiveness. In this Special Issue, the authors conclude that many of the states' concerns are legitimate with the issue of duration of proceedings attracting perhaps the least concern. The question is therefore which of the procedural options canvassed in the UNCITRAL WG III process may best address the concerns. We can conclude with reflections on the four reform options and three caveats in light of the analysis by members of the ISDS Academic Forum.

First, the articles indicate that incremental reforms of the current investorState arbitration system may have a significant impact in certain areas. Soft and even hard law instruments addressing issues from disclosure of TPF, regulation of double hatting and measures to ensure speedier constitution of tribunals and consolidation of claims can address many concerns. ${ }^{59}$ However, the analysis reveals that the extent to which such 'improvements' of investorState arbitration will contribute to resolving concerns varies dramatically. If the concern is driven fundamentally by the very nature of arbitration (e.g.

$5^{8}$ Although UNCITRAL has drawn up the Transparency Rules and the Mauritius Convention on Transparency.

59 See also Stavros Brekoulakis and Catherine Rogers, "Third-Party Financing in ISDS: A Framework for Understanding Practice and Policy' (31 July 2019) Academic Forum on ISDS Concept Paper 2019/11; Chiara Giorgetti and Mohammed Wahab, 'A Code of Conduct for Arbitrators and Judges' (13 October 2019) Academic Forum on ISDS Concept Paper 2019/12. 
decentralization, party appointment, ad hoc proceedings), this reform option tends to perform more poorly.

Second, the articles suggest that the combination of investor-State arbitration with an appeals mechanism could contribute strongly to alleviating concerns over consistency, and most likely independence/ impartiality. One can almost say that the raison dêtre for such centralization of final decisionmaking is ensuring greater consistency; and most proposed models for appellate review involve permanent bodies not party appointment, addressing at least one major worry over independence. However, it is less clear how this appellate option would impact concerns over diversity and correctness: only a small group of adjudicators would hear appeals and it is not always clear that a 'second look' at a case will be a better look. The answer lies in the eventual design of the appointment process. Will highly representative approaches be chosen in establishing an appellate review mechanism? ${ }^{60}$ Will the mandate and process foreground addressing concerns with correctness? As to duration and costs, the result is even more contingent. Enhanced review of awards could potentially lengthen proceedings and increase costs or it could provide more legal certainty and reduce both. It is almost impossible to predict the likely outcome on this score without considering concrete design options the devil is definitely in the detail.

Third, the creation of a MIC provides an opportunity to address simultaneously several concerns, but not necessarily all. Most likely, tribunal costs would be directly reduced for parties and counsel costs could fall indirectly, through procedural economies of scale and strong possibilities (for states as principals) and incentives (for judges) to introduce case management approaches. However, case proceedings may lengthen if the court does not have an effective means of managing its case load - e.g. addressing more easily small claims, dismissing frivolous claims, or having the service of an effective secretariat. Consistency may be enhanced through a smaller number of adjudicators and a centralized secretariat but whether correctness will be improved is more challenging. Some critics of the MIC reform maintained that MIC judges are less likely to be skilled in the commercial and factual dimensions of cases, whereas others contend that the experience of domestic and international courts

6o See discussion of highly representative models of appeal review in: Olof Larsson and others, 'Selection and Appointment in International Adjudication: Insights from Political Science' (17 September 2019) Academic Forum on ISDS Concept Paper 2019/10; Andrea $\mathrm{K}$ Bjorklund and others, 'Selection and Appointment of International Adjudicators: Structural Options for ISDS Reform' (24 September 2019) Academic Forum on ISDS Concept Paper 2019/11; Langford, Behn, and Malaguti (n 37). 
demonstrates how quickly judges can master this competence.$^{61}$ Finally, there are clear opportunities to ensure diversity, although it may require very clear requirements (especially on gender) if any change will be secured;62 and the removal of party appointment would reduce concerns about affiliation bias (impartiality concern) and repeat appointment by the same party (independence concern). Some worry though that independence and impartiality will be threatened by a greater involvement of states in appointment processes; although it has been pointed out that states as principals in party appointment have very different interests than states as parties in litigation. ${ }^{63}$

Fourth, the more transformative or paradigmatic option of 'no ISDS' is the most difficult reform option to assess. This option of state-to-state arbitration or domestic courts can, often simultaneously, strongly address and exacerbate WG III concerns. For example, with the greater use of domestic courts, geographic diversity may be decreased at a case level and enhanced on a systemic level. The likelihood of greater inconsistency is high with both No ISDS options while there is significant disagreement on whether correctness may be improved: adjudicators will have less experience with investment treaty law, but possibly more with the factual context. The removal of ISDS may positively address independence (e.g. concerns with party appointment), while potentially raising new ones (especially when cases are taken in domestic courts of the respondent state). The divergent findings for the 'no ISDS' option should be no surprise, however. This reform option is not especially motivated by the formal concerns concerning ISDS in WG III. It is driven equally by concerns with the substantive treaties and the mere existence of international review.

Parsing the Special Issue, it is somewhat clear that reforms which promote greater institutionalization and centralization can address many of the concerns addressed by UNCITRAL WG III. This is because such options restructure the underlying form of adjudication. However, three caveats must be made to such a conclusion. The first is that structural reforms do not directly or necessarily address substantive concerns with the treaties meaning that only part of the legitimacy crisis might be addressed. ${ }^{64}$ Indeed, some fear that a structural reform will give the illusion of real reform, legitimating what they consider as problematic aspects of the treaties - e.g. vague

61 This discussion in WG III has been tightly summarised at UNCITRAL, 'Report of Working Group III (Investor-State Dispute Settlement Reform) on the Work of Its Resumed Thirty-Eighth Session' (Vienna, 20-24 January 2020, published 28 January 2020) UN Doc A/CN.9/1004/Add.1.

62 See Larsson and others (n 6o).

63 UNCITRAL (n 61).

64 Dimitropoulos (n 20). 
FET clauses and damages provisions that permit expansive interpretations. Conversely, the second caveat is that strong centralization could have unintended consequences. It may incentivize large investors to turn exclusively to contracts and commercial arbitration, amplifying further concerns around transparency and independence. The third is that more ambitious structural reforms may take longer to implement or attract support, raising the risk of the 'best being the enemy of the good'.

Each of these caveats raises ultimately questions that are neither technical nor legal. The ongoing construction of the legal mandate is political; and the dance of inducing current and future consensus amongst diverse actors is political. Thus, the way the UNCITRAL reform process proceeds will matter as much as how states develop specific design options. A successful reform on the UNCITRAL WG III's own terms - to address the real and perceived legitimacy of the investment regime - will require both an optimal palette of reforms ${ }^{65}$ and an artful management of internal and external politics.

65 See particularly Sergio Puig and Gregory Shaffer, 'Imperfect Alternatives: Institutional Choice and the Reform of Investment Law' (2018) 112 AJIL 361, 379-83. 